\title{
Allelopathic Evidence in Exotic Guava (Psidium guajava L.)
}

\author{
Tatiani Elisa Chapla ${ }^{1}$ and João Batista Campos $^{2 *}$ \\ ${ }^{1}$ Universidade Estadual de Maringá; Avenida Colombo, 5790; Zona 7; 87020-900; Maringá - PR - Brasil. ${ }^{2}$ Instituto \\ Ambiental do Paraná; Av. Bento Munhoz da Rocha Neto, 16; Zona 7; 87020-170; Maringá - PR - Brasil
}

\begin{abstract}
The allelopathic activity of the leaf aqueous extract of guava (Psidium guajava L.) on seed germination and root growth in lettuce (Lactuca sativa L.) was studied in an experiment consisting of four replicates with 10 seeds each and extract concentrations of 5, 10, and 20\%. Guava allelopathic activity occurred during the germination and growth of lettuce roots at $20 \%$ extract concentration, as shown by ANOVA. This result suggested the allelopathic potential of the species. Therefore, the success of $\mathrm{P}$. guajava in invading environments could be partially due to allelopathy. Further studies using other plant parts and field experiments should be conducted.
\end{abstract}

Key-words: Abandoned pastures, allelopathy, biological invasion, riparian vegetation, seeds

\section{INTRODUCTION}

In several countries, the number and proportion of flora and fauna exotic species are extremely high (Sandlund et al., 2001). Plant invasions are a threat to biodiversity and to the stability of native ecosystems, and can also affect ecosystem functioning and processes (Ehrenfeld, 2003; Mack et al., 2001).

Commonly known as guava tree, Psidium guajava L. is a Myrtaceae originally from Central America from Southern Mexico to Northern South America (Morton, 1987). The species has been registered as invasive in pasture (Somarriba, 1985) and as an important pioneer species in the process of forest recovery on abandoned pasture (Aide et al., 2000; Berens, 2008). The success of $P$. guajava in occupying pasture is often attributed to its regrowth ability and to the dispersion of its seeds by birds and cattle (Berens, 2008, Somarriba, 1985). The $P$. guajava has been registered as an invasive species of secondary forests on abandoned pasture in the Upper Paraná River Floodplain (Campos and Dickinson, 2005). Understories dominated by $P$. guajava are poorer in species and specimens than areas dominated by native species (Chapla et al., 2008).

Allelopathy, defined as "the release of phytotoxins by the plants" (Bais et al., 2003), has been considered a mechanism for the success of invasive plants (Hierro and Callaway, 2003) due to the phytotoxin effect on the growth and biological processes of other species in the community (Ridenour and Callaway, 2001). Previous studies on guava allelopathic effects on other species were conducted only with guava roots and fruits (Bovey and Diaz-Colon, 1968; Brown et al., 1983). Therefore, guava allelopathic potential can be an additional factor in determining its success as an invasive species.

Based on the need to understand the invasive species and the processes occurring during the invasion (Sandlund et al., 2001), this study was designed to evaluate the allelopathic activity of different concentrations of the leaf aqueous extract of guava (Psidium guajava L.) on the germination

\footnotetext{
* Author for correspondence: redebio@wnet.com.br
} 
and root growth in lettuce (Lactuca sativa L.) (a standard for allelopathic tests) (Ferreira and Aquila, 2000).

\section{MATERIALS AND METHODS}

Plant material - The green leaves of $P$. guajava were collected at Santa Rosa Island in the Paraná River, municipality of Porto Rico, State of Paraná, on April 3 $3^{\text {rd }} 2008$ (22 $46^{\prime} 23^{\prime \prime} S$ and $53^{\circ} 18^{\prime} 15^{\prime \prime} \mathrm{W}$ ). The plants were placed in transparent plastic bags and kept refrigerated. On the following day, the material was taken to the laboratory at Universidade Estadual de Maringá, where the experiment was conducted.

Plant extracts - The leaves were washed in running water. Next, 100 grams of whole leaves were blended with $500 \mathrm{~mL}$ distilled water. The leaf extract obtained was filtered through a cotton cloth and concentrated to 20,10 and 5\% extract (Scherer et al., 2005).

Tests - A filter paper sheet placed on a Petri dish received $2 \mathrm{~mL}$ extract or distilled water (as control). Four replicates with 10 seeds (commercial seeds) of $L$. sativa were used for each treatment. The dishes were placed in a germination chamber at $25^{\circ} \mathrm{C}$ and 12-hour photoperiod (Usberti and Felipe, 1980). Germinated seeds were counted after 24,48 , and $72 \mathrm{~h}$, and all the rootlets greater than $2 \mathrm{~mm}$ in length (Hadas, 1976) were measured with a calliper.

Data analysis - The two-way ANOVA was used to measure the extract effect on the germination and root growth (Zar, 1999), where the factors were number of hours and extract concentrations at 5\% significance. The means for germinated seeds and for root length were compared by the Tukey test at 5\% significance (Zar, 1999). The statistical tests were processed using STATISTICA for Windows (Stasoft, 2005).

\section{RESULTS AND DISCUSSION}

The mean for the germinated seeds was $8 \pm 1$ (germinated seeds per dish \pm standard error) for the control and the 5\% and $10 \%$ concentrations, and $7 \pm 1$ (germinated seeds per dish \pm standard error) for the $20 \%$ concentration. ANOVA showed differences in the means (Table 1). According to the Tukey test, the allelopathic effect of the leaf aqueous extract of $P$. guajava on the germination of $L$. sativa occurred only at $20 \%$ concentration.

The mean root length of $L$. sativa decreased with the increase in extract concentration (Table 2). According to ANOVA and the Tukey test, root growth in L. sativa was also affected by the leaf aqueous extract of $P$. guajava only at $20 \%$ concentration (Table 3).

These results pointed to a potential allelopathic effect of $P$. guajava leaves on the seed germination and root growth of other species. From an ecological viewpoint, the inhibition of plant development after germination is a selection strategy that ignores the descent (Jacobi and Ferreira, 1991). Therefore, if $P$. guajava is a successful exotic invasive species in riparian areas, it can lead to lower diversity, particularly in areas of forest recovery.

Table 1 - ANOVA results for effect of leaf aqueous extract of P. guajava at different concentrations (control, 5\%, $10 \%$, and $20 \%$ ) on the germination of L. sativa. Effects of interaction among factors.

\begin{tabular}{lcc}
\hline Factor & F & P \\
\hline Treatment & 3.184 & $\mathbf{0 . 0 3 5}$ \\
Number of hours & 20.640 & $\mathbf{0 . 0 0 0}$ \\
Treatment X Number of hours & 1.774 & 0.132 \\
\hline
\end{tabular}

Table 2 - Mean root length $(\mathrm{mm})$ of $L$. sativa \pm standard error per treatment.

\begin{tabular}{lccc}
\hline Treatment & $\mathbf{2 4 h}$ & $\mathbf{4 8 h}$ & $\mathbf{7 2 h}$ \\
\hline Control & $2.56^{ \pm 0.3}$ & $7.56^{ \pm 0.56}$ & $14^{ \pm 1,12}$ \\
$5 \%$ & $2.02^{ \pm 0.3}$ & $7.67^{ \pm 0.6}$ & $13.88^{ \pm 1.64}$ \\
$10 \%$ & $1.36^{ \pm 0.28}$ & $5.76^{ \pm 0.67}$ & $11.21^{ \pm 2.51}$ \\
$20 \%$ & $0.9^{ \pm 0.05}$ & $4.58^{ \pm 0.45}$ & $8^{ \pm 1}$ \\
\hline
\end{tabular}


Table 3 - ANOVA results for effect of leaf aqueous extract of P. guajava at different concentrations (control, 5\%, $10 \%$, and $20 \%$ ) on root growth in L. sativa. Effects of interaction among factors.

\begin{tabular}{lcc}
\hline Factor & F & P \\
\hline Treatment & 13.129 & $\mathbf{0 . 0 0 0}$ \\
Number of hours & 172.010 & $\mathbf{0 . 0 0 0}$ \\
Treatment X Number of hours & 0.634 & 0.702 \\
\hline
\end{tabular}

Previous studies on the chemical composition of guava leaves have identified chemical products belonging to the groups with allelopathic properties (Monteiro and Vieira, 2002), such as the terpenoids, flavonoids, coumarins, cyanogenic acids, among others (Begum et al., 2002; Gutiérrez et al., 2008). Some of these, such as the terpenoids can be lixiviated from the leaves by rain (Monteiro and Vieira, 2002). Some studies have already identified guava allelopathic effects on other species, the effect of guava fruit extracts on cucumber germination (Cucumis sativus) (Bovey and Diaz-Colon, 1968), as well as the effect of guava root exudates on lettuce (L. sativa) germination and root growth, and the root growth of bristly foxtail (Setaria verticillata) (Brown et al., 1983). The antibacterial activities of guava leaves aqueous extract has also been reported (Sanches et al., 2005), which may imply effects on soil microbiota and cause more widespread effects such as on the functioning of the ecosystem. Therefore, the significant success of $P$. guajava in invading abandoned pastures could be partially caused by allelopathy, primarily due to its ability to decrease the diversity in the lower forest strata (Chapla et al., 2008). Further study is needed on the allelopathic effect of guava on native species in riparian forests and on other plant parts such as fruit, rhytidome, root, and senescent leaves. Field experiments are also needed (Barbosa et al., 2008) because under natural conditions, the variety of guava interactions with the physical environment and other organisms can either intensify or decrease its allelopathic effects (Inderjit and Callaway, 2003).

\section{ACKNOWLEDGMENTS}

We would like to thank R. B. Rodrigues, M. C. Teixeira and José Cândido. We also thank anonymous reviewers, whose comments improved considerably this manuscript. The following organizations supported this work: Nupélia (Núcleo de Pesquisas em Limnologia, Ictiologia e
Aquicultura), Programa de Pós-Graduação em Ecologia de Ambientes Aquáticos Continentais PEA, Universidade Estadual de Maringá - UEM, Instituto Ambiental do Paraná - IAP, CNPq (Conselho Nacional de Desenvolvimento Científico e Tecnológico), Peld (Pesquisas Ecológicas de Longa duração - sítio 6), and Programa Paraná Biodiversidade.

\section{RESUMO}

Com a finalidade de avaliar a atividade alelopática do extrato aquoso de folha da goiabeira (Psidium guajava L.) sobre a germinação e crescimento de raiz de alface (Lactuca sativa $\mathrm{L}$.) foi aplicado um experimento com concentrações de extrato à 5,10 e $20 \%$, com 4 repetições e 10 sementes cada uma. Por meio de uma ANOVA, foi verificado atividade alelopática da goiabeira sobre a germinação e crescimento da raiz de alface na concentração de 20\%, indicando o potencial alelopático da espécie. Desta forma, o sucesso de Psidium guajava em invadir ambientes pode ser atribuído, em parte, à alelopatia. Recomendamos mais estudos com outras partes da planta e experimentos em campo.

\section{REFERENCES}

Aide, T. M., Zimmerman, J. K., Pascarella, J. B., Rivera, L. and Marcano-Vega, H. (2000), Forest regeneration in a chronosequence of tropical abandoned pastures: implications for restoration ecology. Rest. Ecol, 8, 328-338.

Bais, H. P., Vepachedu, R., Gilroy, S., Callaway, R. M. and Vivanco, J. M. (2003), Allelopathy and exotic plant invasion: from molecules and genes to species interactions. Science 301, 1377-1380.

Barbosa, E. G., Pivello, V. R. and Meirelles, S. T. (2008), Allelopathic evidence in Brachiaria decumbens and its potential to invade the Brazilian cerrados. Braz. Arch. Bio. Tech., Curitiba-PR, 51, 825-831. 
Begum, S., Hassan, S. I., Siddiqui, B. S., Shaheen, F., Ghayur, M. N. and Gilani, A. H. (2002), Triterpenoids from leaves of Psidium guajava. Phytochemistry, 61, 399-403.

Berens, D.G., Farwig, N., Schaab, G. and BöhningGaese, K. (2008), Exotic guavas are foci of forest regeneration in Kenyan farmland. Biotropica, 40, 104-112.

Bovey, R. W. and Diaz-Colon, J. D. (1968), Occurrence of plant growth inhibitors in tropical e subtropical vegetation. Phys. Plant., 22, 253-259.

Brown, R.L., Tang, C. S. and Nishimoto, R. K. (1983), Growth-inhibition from guava roots exudates. Hortscience, 18, 316-318.

Campos, J.B. and Dickinson, G. (2005), Regeneração de florestas na Área de Proteção Ambiental - APA das Ilhas e Várzeas do Rio Paraná. Cad. biodivers., 5, 50-59.

Chapla, T. E., Zampar, R. and Campos, J. B. (2008), Invasão biológica e perda de diversidade em parcelas permanentes na APA das ilhas e várzeas do rio Paraná. Abstract presented at I Seminário nacional sobre dinâmica de florestas, 23-26 june, Curitiba, Brazil

Ehrenfeld, J. G. (2003), Effects of exotic plant invasions on soil nutrient cycling processes. Ecosystems, 6, 503-523.

Ferreira, A. and Aquila, M. E. A. (2000), Alelopatia: uma área emergente da ecofisiologia. Rev. Bras. Fisiol. Veg., 12, 175-204.

Gutiérrez, R. M. P., Mitchell, S. and Solis, R. V. (2008), Psidium guajava: A review of its traditional uses, phytochemistry and pharmacology. $J$. Ethnopharm., 117, 1-27.

Hadas, A. (1976) Water uptake and germination of leguminous seeds under changing external water potential in osmotic solution. J. Exp. Bot., 27, 480-89.

Hierro, J. L. and Callaway, R. M. (2003), Allelopathy and exotic plant invasion. Plant and Soil, 256, 29-39.

Inderjit and Callaway, R. M. (2003), Experimental designs for the study of allelopathy. Plant and soil, 256, 1-11.

Jacobi, U. S. and Ferreira, A. G. (1991), Efeitos alelopáticos de Mimosa bimunocrata (DC) OK sobre espécies cultivadas. Pesq. Agrop. Bras., 26, 935-943.
Mack, R. N., Simberloff, D., Lonsdale, M., Evans, H., Clout, M. and Bazzaz, F. (2001), Biotic invasions: Causes, epidemiology, global consequences, and control. Ecol. App., 10, 689-710.

Monteiro, C. de A. and Vieira, E. L. (2002), Substâncias alelopáticas. In: Castro, P. R. de C. e, Sena, J. O. A. de and Kluge, R. A. Introdução à fisiologia do desenvolvimento vegetal. Maringá-PR: Eduem.

Morton, J. F. (1987), Fruits of warm climates. Creative Res. Syst. Inc. 91-102.

Ridenour, W. M. and Callaway, R. M. (2001), The relative importance of allelopathy in interference: the effects of an invasive weed on a native bunchgrass. Oecologia 126, 444-450.

Sanches, N. R., Cortez, D. A. G., Schiavini, M. S., Nakamura, C. V. and Dias-Filho, B. P. (2005), An evaluation of antibacterial activities of Psidium guajava (L.). Braz. Arch. Bio. Tech., Curitiba-PR, 48, 429-436.

Sandlund, O. T., Schei, P. J. and Viken, A. (2001), Invasive species and biodiversity management. Netherlands: Kluver academic publishers.

Scherer, L. M., Zucareli, V., Zucareli, C. A. and Fortes, A. M. T. (2005), Efeito alelopático do extrato aquoso de folha e de fruto de leucena (Leucaena leucocephala Wit) sobre a germinação e crescimento de raiz da canafístula (Peltophorum dubiam Spreng.). Semina: Cienc. Agr., Londrina-PR, 26, 161-166.

Somarriba, E. (1985), Arboles de guayaba (Psidium guajava L.) em pastizales. II consumo de fruta $\mathrm{y}$ dispersion de semillas. Turrialba, 35, 329-332.

Stasoft, Inc. (2005), STATISTICA for Windows [Data analysis software system] version 7.1. Tulsa, Oklahoma.

Usberti, R. and Felipe, G. M. (1980), Viabilidade de sementes de Citrus limonia Osb. com baixo teor de umidade, armazenada em diferentes temperaturas. Pesq. Agrop. Bras., 15, 393-397.

Zar, J. H. (1999), Biostatistical Analysis. New Jersey: Prentice Hall, 4ed. 